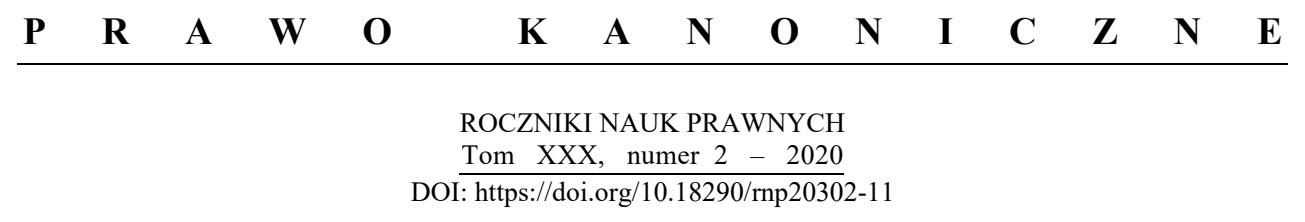

LESZEK ADAMOWICZ

\title{
MIŁOSIERDZIE W PRAWIE KATOLICKICH KOŚCIOŁÓW WSCHODNICH
}

Jedynym miejscem w Kodeksie Kanonów Kościołów Wschodnich, w którym Prawodawca odwołuje się wyraźnie do miłosierdzia, jest kan. 732, w którym nakreślając zasadnicze obowiązki spowiednika przypomina, że „kapłan powinien pamiętać, że Bóg ustanowił go szafarzem Bożej sprawiedliwości i miłosierdzia, dlatego jako ojciec duchowny powinien także odpowiednio udzielić rady, w jaki sposób penitent może wzrosnąć w swoim powołaniu do świętości” (§ 2) i dlatego ,powinien zastosować odpowiednie do choroby lekarstwo, nakładając należne czyny pokutne, stosownie do rodzaju, ciężkości i liczby grzechów, z uwzględnieniem sytuacji penitenta i jego dyspozycji do nawrócenia” $(\S 1)^{1}$.

Czy jednak rzeczywiście na tym kończy się odwołanie się do miłosierdzia w prawie kanonicznym? Odpowiedź na to pytanie bez cienia wątpliwości winna być negatywna. Bowiem poza wyżej zacytowanym odwołaniem się do posługi miłosierdzia, którą podejmuje spowiednik, w katolickich kodyfikacjach prawnych można wydobyć wiele innych przepisów, które bezpośrednio lub pośrednio dotykają tej rzeczywistości.

\footnotetext{
Ks. dr hab. LeSZEK AdAmowicz, prof. KUL - Katedra Kościelnego Prawa Procesowego, Małżeńskiego i Karnego oraz Katolickich Kościołów Wschodnich, Instytut Prawa Kanonicznego, Wydział Prawa, Prawa Kanonicznego i Administracyjnego Katolickiego Uniwersytetu Lubelskiego Jana Pawła II, dyrektor Centrum Prawa Katolickich Kościołów KUL, Al. Racławickie 14, 20-950 Lublin; e-mail: adleszek@kul.pl; ORCID: https://orcid.org/0000-0003-2513-4243

${ }^{1}$ Can. $732 \S 1$. Pro qualitate, gravitate et numero peccatorum, habita ratione paenitentis condicionis necnon eiusdem ad conversionem dispositionis, confessarius convenientem morbo afferat medicinam opportuna opera paenitentiae imponens. $\S 2$. Meminerit sacerdos se divinae iustitiae et misericordiae ministrum a Deo constitutum esse; tamquam pater spiritualis etiam opportuna consilia praebeat, ut quis progredi possit in sua vocatione ad sanctitatem.
} 


\section{ECCLESIA - DISPENSATOR MISERICORDIAE}

Pierwsza i zasadnicza konstatacja dotyczy samego Kościoła, ustanowionego przez Boskiego Założyciela, by w nim urzeczywistniała się tajemnica Bożego miłosierdzia. Zabezpieczenie wierności w wypełnianiu tego posłannictwa stanowi najgłębsze, i poniekąd jedyne, uzasadnienie dla prawa kościelnego. Dlatego też przepisy odnoszące się do przekazywania doktryny, sprawowania kultu Bożego, szczególnie sakramentów świętych, duszpasterskich struktur hierarchicznych stanowią ramy prawne, w których salus animarum suprema lex semper esse debet. Nie bez racji można się odwołać do nauczania jednego z najznakomitszych papieży średniowiecza, w którym upatrywano nadzieje upadającego Rzymu, św. Leona Wielkiego.

W jednej z „Mów na Zesłanie Ducha Świętego” ów papież wyraża myśl, iż przez posługę głoszenia słowa Bożego w sercach słuchaczy dokonuje się ,rozdawnictwo darów Bożych (dispensatio munerum divinorum)" ". Według znawców pism tego papieża, „ta z pozoru nieznacząca wzmianka ma w rzeczywistości doniosłe znaczenie. Pojawiający się w tym sformułowaniu termin $d i$ spensatio thumaczy się jako „rozdzielanie, udzielanie, zarządzanie”. Można go odnaleźć także w innych Mowach św. Leona, w których mówi np. że „działalność Chrystusa w ciele ziemskim (dispensatio actionum corporalium)" przeszła na wyżyny chwały; że w „szafarstwie tajemnic Chrystusa (in dispensationibus sacramentorum Christi)" człowiek otrzymuje siłę i wzór do naśladowania; że łaska „wchodzi w skład szafarstwa i porządek nabożeństw (dispensationum ordine)"; czy też stwierdza, iż całe zbawcze mysterium/ sacramentum ,jest wypływem miłosierdzia (dispensatio fuit misericordiae)" samego Boga. Termin dispensatio jest łacińskim odpowiednikiem greckiego oikonomia (mocno związanego z misterion) oznaczającego w języku teologicznym stopniowe urzeczywistnianie Bożego planu zbawienia w historii ${ }^{3}$.

Stąd też Kościół jest depozytariuszem i „zarządcą” Bożego miłosierdzia. Od chwili, w której Chrystus ,zinstytucjonalizował” środki zbawienia, czyli Słowo i sakramenty, powierzając ich administrowanie Kościołowi poprzez

\footnotetext{
2 Św. LeON WIELKI, Sermo 76, 1, PL 54, 404B-C, POK 24, 365: „Nie obawiamy się też, żeby te rzeczy, znane już ludziom uduchowionym i światłym, miały ich znudzić. Boć zyskują oni tylko na tym, jeśli pragną wtajemniczenia jak największej ilości ludzi w to, czego sami z tak wielkim pożytkiem się na uczyli. Niech się tedy iści rozdawnictwo darów Bożych (dispensatio munerum divinorum) w sercach wszystkich! Niechaj nikt - więcej czy mniej obeznany z nauką chrześcijańską - nie gardzi naszą posługą słowa!".

${ }^{3}$ M. DĄBRówKA, Istota postugi głoszenia Stowa Bożego w świetle „Mów” św. Leona Wielkiego, „Vox Patrum” 34 (2014), t. 62, s. 93-112 (tutaj: s. 109).
} 
jego szafarzy, te środki zbawienia stały się także treścią przepisów prawa. Łaska zawarta i przekazywana przez sakramenty i moc zbawcza depozytu wiary są nie tylko darem darmo przekazanym przez miłosierdzie Boże, ale stanowią także przedmiot uprawnień ochrzczonych $\mathrm{w}$ relacji do szafarzy Kościoła (zob. np. kan. 213 KPK i kan. $16 \mathrm{KKKW})^{4}$.

Można wręcz stwierdzić z jednej strony, że wierni mają prawo ubiegać się o miłosierdzie Boże, zarówno w sensie bezpośredniej relacji z Bogiem, ale także w odniesieniu do szafarzy Kościoła. Natomiast szafarze mają wynikający ze sprawiedliwości obowiązek rozszerzania miłosierdzia Bożego, gdyż Słowo i sakrament nie są ich własnością, ale dobrami powierzonymi Kościołowi, którymi tenże Kościół jedynie zarządza, posiadając nawet uprawnienie do przebaczania in nomine Dei-Patris misericordiae, którego dokonuje spowiednik w sakramencie pokuty i pojednania ${ }^{5}$.

Prawdziwość, czyli nie tylko ważność i legalność sprawowania sakramentów, ale także zadbanie o ich godziwość i owocne ich sprawowanie i przyjęcie, stanowią warunki rzetelnej posługi na rzecz miłosierdzia, które jako łaska sakramentalna stanowi oczekiwany owoc świętych znaków sakramentalnych. $\mathrm{Na}$ straży tych zbawczych skutków stoi m.in. prawo kanoniczne i przepisy liturgiczne. Ten sam sposób rozumowania należy zastosować także do przekazu doktryny, by zachować treść nauczania Chrystusa w formie nienaruszonej, chronionej przez przepisy Kościoła dotyczące posługi nauczania $\mathrm{w}$ formie przepowiadania słowa Bożego, katechizacji, działalności misyjnej i ekumenicznej.

W wyżej wskazanej trosce o prawdziwość znaku sakramentalnego i nieskazitelność przekazu depozytu wiary szczególną rolę mają do wypełnienia papież i pozostali biskupi. Stąd też także ochrona prawna i doprecyzowanie praw i obowiązków hierarchów ma olbrzymie znaczenie dlatego, by Kościół uporządkowany hierarchicznie, był szafarzem Bożego miłosierdzia. Szczególnie warta podkreślenia jest posługa biskupów jako głównych szafarzy sakramentów i stróżów życia liturgicznego oraz jako nauczycieli wiary, którzy sami głoszą naukę o miłosiernym Bogu i udzielają misji kanonicznej innym (poprzez święcenia lub akt administracyjny) do głoszenia tego orędzia. Wymierzając natomiast kary tym wiernym, których należy tym sposobem nakłonić do nawrócenia, nie można, jak stanowi prawodawca w kan. $1401 \mathrm{KKKW}$, „nakładać

\footnotetext{
${ }^{4}$ Ius est christifidelibus, ut ex spiritualibus Ecclesiae bonis, praesertim ex verbo Dei et sacramentis, adiumenta ab Ecclesiae Pastoribus accipiant.

${ }^{5}$ Zob. E. BAURA DE LA PEÑA, Misericordia, oikonomia e diritto nel sistema matrimoniale canonico, [w:] Misericordia e diritto nel matrimonio, red. C.J. Errázuriz, M.Á. Órtiz, Roma: Edizioni Santa Croce 2014, s. 23-26.
} 
kary w celu takiego wyleczenia ran wyrządzonych przez przestępstwo, by ani nie zepchnąć przestępców w przepaść rozpaczy, ani popuszczaniem cugli nie powodować rozluźnienia obyczajów i pogardy dla prawa”, gdyż „Bóg stara się wszelkimi sposobami przyprowadzić zbłąkaną owcę”, a „ci, którzy otrzymali od Niego władzę związywania i rozwiązywania, mają odpowiednim lekarstwem zaradzić chorobie sprawców przestępstw, ujawniać ich, błagać i ganić z wszelką cierpliwością i umiejętnością". Paradoksalnie więc, wymierzanie kar przez Kościół w osobach hierarchów, a nie tylko unikanie stosowania i łagodzenie kar, służy zbawieniu grzesznika - przestępcy, który jest w ten sposób przynaglany do otwarcia się na Boże miłosierdzie, czyli nawrócenie, i w ten sposób odzyskuje skarb zbawienia wiecznego.

Dlatego też: „Hierarcha, po wysłuchaniu rzecznika sprawiedliwości, może zupełnie odstąpić od wymierzenia kary, jeśli, według osądu samego Hierarchy, zachodzą jednocześnie wszystkie następujące okoliczności: przestępca nie wezwany jeszcze przed sąd, swoje przestępstwo wyjawi Hierarsze na forum zewnętrznym poruszony szczerą pokutą, a także zadbano o odpowiednie naprawienie zgorszenia i szkody" (kan. $1403 \S 1$ ).

\section{DYSPENSA I EPIKEIA}

$\mathrm{Z}$ miłosierdziem, a przynajmniej $\mathrm{z}$ łagodniejszym stosowaniem prawa, związane są instytucje dyspensy i epikei.

Pojęcie dyspensy wywodzi się z języka greckiego, od słowa oikonomia. Odpowiednik tego pojęcia mieści się w łacińskim słowie dispensare. Oznacza ono roztropne administrowanie sprawami i rzeczami społeczności ${ }^{6}$. Łacińskie dispensare oddaje się w słownikach przez rozdzielać, rozdawać, udzielać, równo podzielić, uporządkować, rozważyć, zarządzać, gospodarzyć7

Dispensator to zarządca, administrator, dawca, rozdawca (wszelkiego dobra). Działanie dispensatorie to działanie oszczędnie, rozsądnie, z umiarem, lekko. Dispensatio w literaturze patrystycznej to oikonomia, o której będzie mowa poniżej, a przez którą rozumiano rządy Boże nad światem, niekoniecznie pokrywających się z ludzką logiką, ale realizujące Boży plan zbawienia. Stąd

\footnotetext{
${ }^{6}$ M. ŻUROWSKI, Dyspensowania od prawa powszechnego w świetle Motu proprio „De episcoporum muneribus”, „Prawo Kanoniczne” 10 (1967), nr 3-4, s. 49.

${ }^{7}$ R. SOBAŃSKI, Niezmienność $i$ historyczność prawa w Kościele: prawo Boże i prawo ludzkie, „Prawo Kanoniczne” 40 (1997), nr 1-2, s. 35.
} 
„stróże tajemnic Bożych i szafarze łask” to dispensatores Dei, jak kapłanów nazywa Cyprian (Ep. 59, 1) .

Ponieważ to szafarstwo nie zawsze mieści się w ,zwykłych” regułach, lecz sprawowane przez ludzi musi uwzględniać sytuację wyjątkową, dispensatio nabrała znaczenia uwalniania od obowiązku prawnego wtedy, gdy prawo musi ustąpić przed dobrem. Dispensatio ma więc zawsze walor pozytywny, jest zorientowane na dobro, o które chodzi w prawie kościelnym ${ }^{9}$.

Według Kodeksu Kanonów Kościołów Wschodnich dyspensa to rozluźnienie prawa czysto kościelnego w poszczególnym wypadku. Może być udzielona jedynie dla słusznej i racjonalnej przyczyny z uwzględnieniem okoliczności przypadku i ważności ustawy, od której się dyspensuje; w przeciwnym razie dyspensa jest niegodziwa, a także jest nieważna, chyba że została udzielona przez samego prawodawcę lub wyższą władzę (KKKW, kan. 1536 §).

Dyspensa jest zwolnieniem od obowiązku zachowania ustawy w szczególnym przypadku i dla słusznej przyczyny ${ }^{10}$. Zapewnia ona większą elastyczność prawu, które pozostaje samo w sobie nienaruszone, a osoba fizyczna, prawna czy nawet cała społeczność korzystając z dyspensy może osiągnąć większe dobro duchowe ${ }^{11}$.

Natomiast, gdy nie ma możliwości skontaktowania się z władzą kompetentną dla udzielania dyspensy w poszczególnym wypadku, prawodawca przewiduje uwolnienia od obowiązków przepisów przez siebie samego, a taki akt nosi nazwę epikeia.

Teoretycznie epikeia opiera się na założeniu, że prawodawca wydając dyspozycję o charakterze uniwersalnym, nie jest w stanie przewidzieć wszystkich sytuacji, jakie mogą się przytrafić. Osoba stosująca epikeię stwierdza sądem subiektywnym, że ogólnie ujęta dyspozycja prawna nie uwzględnia całej indywidualnej specyfiki jej sytuacji, dla której sam prawodawca, gdyby ją przewidział, wydałby inną dyspozycję. Taki sąd pozwala zainteresowanej osobie uznać się wolną od obowiązku przestrzegania ustawy jako nieadekwatnej do konkretnej sytuacji ${ }^{12}$.

Bezsporna w tradycji teologii moralnej i kanonistyki dopuszczalność stosowania epikei wynika z realistycznego dostrzeżenia, że adresat niewątpliwie

\footnotetext{
${ }^{8}$ R. SoBAŃSKI, Nauki podstawowe prawa kanonicznego, cz. 1: Teoria prawa kanonicznego, Warszawa: Wydawnictwo Uniwersytetu Kardynała Wyszyńskiego 2001, s. 77.

${ }^{9}$ Tamże.

${ }^{10}$ E. SzTAFrowsKi, Podręcznik prawa kanonicznego, t. I, Warszawa: Wydawnictwo ATK 1985, s. 201.

${ }^{11}$ J. GRZYwaCZ, Dyspensa, [w:] Encyklopedia katolicka, t. IV, Lublin: TN KUL 1995, kol. 446.

${ }^{12}$ R. SOBAŃSKI, Kościót - prawo - zbawienie, Katowice: Księgarnia św. Jacka 1979, s. 285.
} 
obowiązującej normy może w konkretnym przypadku uznać, iż ze względu składające się nań specyficzne elementy norma nie obowiązuje, a nie przestrzegając jej postępuje godziwie. $Z$ punktu widzenia etycznego epikeia pozwala osobie dotkniętej normą prawną zachować się godziwie, mimo że wbrew ustawie. Istotne jest wtedy postępowanie zgodne $\mathrm{z}$ sumieniem. Z punktu widzenia prawnego epikeia wymaga, by oparte na niej zachowanie było nie tylko godziwe, ale i słuszne. Stosując epikeię nie powinien koncentrować się jedynie na specyficznych elementach własnej sytuacji, lecz winien uwzględnić na serio racje stojące za ustawą. Dopiero taki wszechstronny osąd może wskazać zachowania in concreto godziwe i słuszne ${ }^{13}$.

W doktrynie moralistów i kanonistów epikeia ma długą historię. Moraliści omawiają epikeię, gdy uzasadniają, że w określonych sytuacjach nieprzestrzeganie prawa może być godziwe. Samo prawo nie wspomina o epikei, nie jest ona instytucją stricte prawną, ale gdy chodzi o zagadnienie przestrzegania prawa, stanowi przedmiot zainteresowania kanonistów w kontekście obowiązywania prawa.

Tradycja nauki o epikei sięga wywodów Arystotelesa zawartej w Etyce Nikomachejskiej. Opiera się ona na dostrzeżeniu, że prawodawca ustalając normy generalne i abstrakcyjne, nie jest w stanie uwzględniać wszystkich sytuacji indywidualnych, dla których gdyby je przewidział, wydałby odrębne dyspozycje. Epikeia, według Arystotelesa, to korektura prawa w duchu prawodawcy ${ }^{14}$. Epikeia nie jest kompromisem etycznym, lecz uznaniem nadrzędności, słuszności i prawa naturalnego nad prawem pozytywnym. W epikei wyraża się fakt, że w poszczególnych przypadkach postępowanie wbrew ustawie może służyć sprawiedliwości. Według Arystotelesa wszyscy ludzie są obdarzeni praktycznym rozumem, potrafią ocenić wymogi sprawiedliwości, a realia codziennego życia zmuszają ich do stosowania epikei ${ }^{15}$.

Naukę Arystotelesa przejął św. Tomasz z Akwinu, wzbogacając ją pierwiastkiem chrześcijańskim. Tomasz nie widział w epikei chęci pominięcia prawa i uwolnienia się od ciężarów ustawy, lecz właśnie zamiar realizacji wartości przyświecających prawodawcy, gdy wydawał ustawę. Podkreślał on, że należy stosować epikeię, gdy tego wymaga dobro wspólne. Powiązanie epikei ze sprawiedliwością pozwoliło mu mówić o cnocie epikei, która każe nieraz poświęcić sprawiedliwość legalną w imię sprawiedliwości ${ }^{16}$.

\footnotetext{
${ }^{13}$ Tamże, s. 133.

${ }^{14}$ R. SOBAŃSKI, Teoria prawa kościelnego, Warszawa: Wydawnictwo ATK 1992, s. 239.

15 Tamże.

${ }^{16}$ R. SOBAŃSKI, Kościót - prawo-zbawienie, s. 285.
} 
Nie daje się przewidzieć ani racjonalnie zgeneralizować wielości konkretnych przypadków. Powoduje to, że w konkretnej sytuacji rozum winien je rozważać wszechstronnie i wyciągnąć wniosek praktyczny, który może sprzeciwiać się normie generalnej, właśnie ze względu na aspekty sytuacji, których prawodawca nie mógł mieć na uwadze. Postępowanie takie Tomasz uznał za zasadne dlatego, że prawo ludzkie jest podporządkowane prawu naturalnemu oraz prawu Ewangelii. Ze względu na sprawiedliwość człowiek może i powinien odstąpić od ustawy, gdy to nakazuje rozum. Człowiek ma obowiązek tak postępować, gdyby przestrzeganie ustawy narażało sprawiedliwość, wykraczało przeciw prawu naturalnemu lub narażało dobro wspólne. Nieprzestrzeganie ustawy na podstawie epikei, nie jest podyktowane chęcią uwolnienia się od jej ciężaru, obejścia woli prawodawcy, zyskanie własnych korzyści, lecz zamiarem realizacji sprawiedliwości. Chodzi więc o dobro wspólne i sprawiedliwość, a stosowanie epikei to nie sprzeciw przeciwko prawodawcy, lecz chęć spełnienia jego woli. Poświęcenie sprawiedliwości legalnej może i musi czasem mieć miejsce właśnie w imię sprawiedliwości ${ }^{17}$.

Można więc zauważyć, w ślad za św. Tomaszem, że sąd subiektywny prowadzący do zastosowania epikei nie odnosi się do przepisu prawa, lecz do konkretnego przypadku, w którym dany przepis winien być zastosowany. Nie podważa mocy obowiązującej ustawy jako takiej, lecz dotyczy jedynie osoby, która znalazła się w jej zasięgu. Nieprzestrzeganie ustawy ma walor nie tylko etyczny w sensie zachowania się godziwego, lecz także walor prawny w sensie zachowania się słusznego, także z punktu widzenia prawa ${ }^{18}$.

\section{EKONOMIA (OIKONOMIA) I AKRYBIA (AKRIBEIA) ${ }^{19}$}

W toku prac nad przygotowaniem Kodeksu Prawa Kanonicznego Wschodniego podjęto dyskusję na temat zasady ekonomii, która jest jedną z głównych zasad stosowania prawa we wschodnim chrześcijaństwie. Powstały nawet projekty, by zdefiniować tę zasadę i włączyć ją do powstającego kodeksu.

\footnotetext{
${ }^{17}$ R. SOBAŃSKI, Teoria prawa kościelnego, s. 240.

18 Tamże, s. 241.

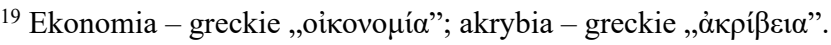


Ekonomia kościelna - stwierdza E. Melia - ma dwa znaczenia lub raczej dwa wymiary: duszpasterski i kanoniczny ${ }^{20}$. Ekonomia w sensie prawnym pozwala biskupowi zachować oficjalny przepis kanonu, wraz z jego niezmiennością, a równocześnie w konkretnym przypadku pominąć go lub zastosować z pewną tolerancją. Stąd ekonomia w teologii prawosławnej przeciwstawiana jest tzw. akrybii, czyli ścisłemu i rygorystycznemu stosowaniu przepisu prawa $^{21}$. Kościół prawosławny, uciekając się bardzo często w swej praktyce do zasady ekonomii, upatruje dla niej uzasadnienie w łagodnym i pełnym miłosierdzia postępowaniu Chrystusa ${ }^{22}$.

W konstytucji dogmatycznej Lumen gentium Soboru Watykańskiego II zawarte jest pouczenie, że lud Boży „ma za głowę Chrystusa, który wydany został za grzechy nasze i zmartwychwstał dla usprawiedliwienia naszego ( $\mathrm{Rz} 4,25)$, a teraz posiadłszy imię, które jest ponad wszelkie imię, chwalebnie panuje w niebie. Udziałem tego ludu stała się godność i wolność synów Bożych, w których sercach Duch Święty mieszka jak w świątyni. Prawem jego stało się nowe przykazanie miłowania, jak Chrystus nas umiłował (por. J 13,34). Celem jego wreszcie - Królestwo Boże" (LG 9) ${ }^{23}$. Prawo w Kościele jest więc jedno, jest to przykazanie Chrystusa w Ewangelii św. Jana (J 13,34; 15,12); przykazanie nowe dane przez Chrystusa jako ostatni testament przed Jego męką i śmiercią. Miłość ta, wykraczająca poza wszelki kodeks, stała się jedynym prawem dla ludu Bożego zgromadzonego w Kościele ustanowionym przez Chrystusa. „Wszelka inna reguła życia, nawet najbardziej surowa, winna być promieniowaniem tego prawa, winna stanowić jego część składową, czerpiąc natchnienie $\mathrm{z}$ tej miłości. Bez wątpienia jest to najbardziej podstawowy wymiar ekonomii każdego kodeksu prawnego w Kościele, która łączy wszelki nakaz kanoniczny z jedynym prawem, prawem miłości Chrystusa zbawiającego człowieka”. Słowa te wypowiedział na Kongresie Prawa Kościołów Wschodnich w Salonikach (22-27 IX 1981) sekretarz Papieskiej Komisji do Spraw Reformy

${ }^{20} \mathrm{E}$. MeliA, Le lien matrimonial d la lumière de la théologie sacramentaire et de la théologie morale de l'Eglise orthodoxe, „Revue de droit canonique” 21 (1971), s. 194; autor zastrzega się jednak, że prawosławna doktryna ekonomii, zwłaszcza gdy chodzi o terminologię, nie została dotąd formalnie wyłożona.

${ }^{21}$ „L'économie est opposée a l'acribie - pisze ten sam autor - c'est-a-dire a rigueur, au point de vue strict de la normé" (tamże, s. 195).

${ }^{22}$ Zob. E. PRZEKOP, Czy zasada tzw. ,ekonomii” wejdzie do kodeksu prawa dla katolickich Kościołów wschodnich, „Studia Płockie” 12 (1984), s. 87-97.

${ }^{23}$ Sacrosanctum Concilium OeCumenicum Vaticanum II, Constitutio dogmatica de Ecclesia „Lumen gentium” (21.11.1964), AAS 57 (1965), s. 5-71; tekst polski w: SOBÓR WATYKAŃSKI II, Konstytucje, dekrety, deklaracje, Poznań: Pallottinum 2002, s. 161. 
Kodeksu Wschodniego - I. Žužek, jednocześnie profesor Papieskiego Instytutu Wschodniego w Rzymie ${ }^{24}$.

Kościół jako instytucja jest więc środkiem bosko-ludzkim, powołanym do kierowania każdego człowieka ku Chrystusowi, ku wiecznemu zbawieniu. W rezultacie takiego założenia wszelkie prawo kanoniczne, każdy kanon czy jakikolwiek nakaz ogłoszony przez Kościół winien zawsze wchodzić w zakres ekonomii zbawienia i wyrażać ją na zewnątrz. Prawo kanoniczne musi być zatem tak pomyślane, aby wszelka norma prawna w nim zawarta i każdy przepis odpowiadały takiej właśnie ekonomii. W przypadku, gdy konkretny przepis, w konkretnych okolicznościach, narusza zasadę ekonomii, zarówno gdy chodzi o dobro całego Kościoła, jak i poszczególnych jego jednostek, wtedy w samej ustawie muszą być przewidziane odpowiednie środki prawne, by do tego nie dopuścić. Przez posługiwanie się więc środkami przewidzianymi przez same kanony (jak np. dyspensa, uważnienie w zawiązku, legitymacja, uzupełnienie jurysdykcji itd.) - by posłużyć się słowami raportu z pierwszej Konferencji Panprawosławnej - pozostaje się „w poprawnej i całkowitej zgodności z kanonami ustalonymi przez Kościół" 25 . Zarazem uchyla się w konkretnych okolicznościach ich nakazy lub zakazy, jeśli tylko okazują się one szkodliwe dla zbawienia dusz. Uciekając się do stosowania takich właśnie środków prawnych, rzadkie będą wypadki odchodzenia od zasady ekonomii. Przeciwnie, jak stwierdza Žužek, będzie to „najlepszy ze sposobów zachowywania najgłębiej pojętej ekonomii kodeksu"26.

Jeżeli więc wschodni zwyczaj ekonomii, jak chcą tego prawosławni, bywa niekiedy utożsamiany z władzą kanoniczną lub duszpasterską Kościoła, szeroka władza dyspensowania biskupów katolickich jest przejawem tej samej troski pastoralnej. Podkreśla ona zdecydowanie wyraźnie, że naczelnym zadaniem biskupa w Kościele jest obowiązek dobrego pasterza, który zna swoje owce po imieniu (J 10,1-18). Stosuje on umiejętnie przepisy prawa kanonicznego do poszczególnych wypadków, korzystając w razie potrzeby z władzy dyspensowania, przyznanej mu tak szczodrze przez najwyższego prawodawcę kościelnego. I chociaż kodeksy prawne Kościoła katolickiego nie mówią wyraźnie o ekonomii, jednakże w kontekście szerokiej władzy dyspensowania, jaką posiadają dziś biskupi, „rozmiary ekonomii [...] - co podkreśla Žužek - osiągnęły w nich swój punkt kulminacyjny" ${ }^{, 27}$.

\footnotetext{
${ }^{24}$ Maszynopis referatu I. Žužka, zatytułowany „L'économie dans les travaux de la Commission Pontificale pour la Révision de Code de Droit Canonique Oriental”, znajduje się w posiadaniu autora.

${ }^{25}$ Raport ten zamieszcza „Istina” 18 (1973), s. 372-383. Cyt. za: E. PrzeKoP, Czy zasada, s. 90.

${ }^{26}$ „L'économie dans les travaux de la Commission”, s. 5.

${ }^{27}$ Tamże, s. 8.
} 
Pod koniec tego punktu rozważań należy skierować uwagę na jeszcze jedną „zasadę wytyczną”. Wymaga ona mianowicie, by kodeks dla katolickich Kościołów wschodnich odznaczał się charakterem wybitnie duszpasterskim. Zalecenie takie wymaga od autorów nowego kodeksu, by zważali nie tylko na sprawiedliwość, ale także na roztropną słuszność, będącą owocem pobłażania i miłości. Kodeks winien pobudzać pasterzy Kościoła do praktykowania takich właśnie cnót, z całą mądrością i dyskrecją, ażeby reguły kanoniczne nie nakładały obowiązków tam, gdzie instrukcje, pouczenia bądź rady wystarczą same w sobie do właściwego wypełnienia misji Kościoła. Prawodawca winien więc wyposażyć pasterzy Kościoła we władzę dyskrecjonalną, by mogli swobodnie wybierać środki, jakie uznają za pożyteczne dla swoich wiernych, dostosowując je do warunków zmieniającego się życia. Również dobro całego Kościoła wymaga, by normy kodeksowe nie były zbyt sztywne. Większa możliwość manewru pod tym względem, przyznana ordynariuszom, uwypukli jeszcze bardziej duszpasterską naturę kodeksu ${ }^{28}$.

Duszpasterski charakter kodeksu współbrzmi z zasadą ekonomii, że obie te zasady są zbieżne i jeżeli jest się wiernym jednej z nich, to druga zasada pozostaje również zachowana.

Ekonomia, zgodnie z jednomyślną opinią autorów, zakłada więc istnienie przepisów prawa kanonicznego pochodzących od najwyższej władzy ustawodawczej, które nie mogą być uchylone przez władzę niższego stopnia, która jednak uznaje, że w specyficznych okolicznościach zachowanie konkretnego przepisu działa na szkodę Kościoła, dla którego zostało ono wydane. Tym samym o ekonomii można mówić wtedy, gdy biskup lokalny w wyjątkowych okolicznościach postanawia o niezachowaniu przez swoich podwładnych prawa wydanego przez synod lokalny lub sobór powszechny. Trudno natomiast byłoby mówić o ekonomii, gdy sam sobór powszechny staje wobec sytuacji, w której dobro Kościoła wymaga złagodzenia bądź zmiany prawa ogłoszonego przez wcześniejszy sobór. Należałoby raczej wtedy mówić o uchyleniu prawa lub ogłoszeniu nowego.

Z tego, co powiedziano wcześniej, należy wyciągnąć wniosek, że zasada ekonomii zakładająca istnienie przepisów prawa wydanych przez władzę wyższą lub najwyższą, nie może być stosowana w odniesieniu do samego prawodawcy, gdy okazuje się on pobłażliwy w aplikowaniu własnego prawa. Jednakże prawodawca działając w taki sposób, będzie dobrym „ekonomem” w dziedzinie zbawienia dusz.

\footnotetext{
${ }^{28}$ Por. Compiti del coetus III e IV, „Nuntia” 3 (1976), s. 13-14.
} 
Zagadnienie ekonomii było omawiane przez Papieską Komisję do Spraw Reformy Kodeksu Wschodniego Prawa Kanoniczego, która m.in. przeprowadziła badania dotyczące nauki i praktyki ekonomii w tradycji wschodniej i w życiu Kościołów prawosławnych. Po bardzo szczegółowym zapoznaniu się z obszerną bibliografią dotyczącą ekonomii oraz materiałem zebranym w sekretariacie, zredagowano w 1978 r. ostateczny dokument, opublikowany w organie urzędowym Komisji „Nuntia” ${ }^{29}$ w trzech następujących wersjach projektu tekstu kanonu:

I. Oikonomia per quam lex quaedam ecclesiastica non urgetur, sed magis, sub pastorali sollecitudine et vigilantia Hierarchiae Ecclesiae, ad opus salvificum Domini Nostri Jesu Christi provocatur, magni habenda est ${ }^{30}$.

II. § 1. Oikonomia ecclesiastica intelligitur competentia Ecclesiae exercendi opus salvificum Domini Nostri Jesu Christi supplendo ex abundantia eius gratiae et amoris id quod homini in concreto sumpto deest, ut sit in plena conformatione cum sacris canonibus; quapropter Hierarchae, in lege canonica urgenda, magis salutem animarum quam strictam oboedientiam litterae legis intendant ${ }^{31}$.

$\S 2$. Hierarchae debent oikonomiam sollecitudine, vigilantia et cautela exercere, et caveant ne abusus et morum relaxatio christifidelium in hoc exercitio irrepserint ${ }^{32}$.

III. Oikonomia ecclesiastica, qua opus salvificum Domini Nostri Jesu Christi applicatur ita exerceatur sub vigilantia Hierarcharum loci ut ubi observantia legum humano modo difficillima evadit, misericordia divina et amor maternus Ecclesiae suppleat ${ }^{33}$.

Do powyższych tekstów załączono dość obszerne wyjaśnienie:

Ekonomia jest pojęciem teologicznym określającym plan zbawienia dla wszystkich ludzi, dzieło boskiej mądrości. Zgodnie z tym planem Bóg Ojciec posłał swego Syna

${ }^{29}$ Révision des canons De normis generalibus (Archim. Elias Jarawan - Relator), „Nuntia” 10(1980), s. 92-94.

30 „Ekonomia, przez którą ustawa kościelna nie jest urgowana, ale bardziej, pod troską pasterską i czujnością Hierarchii Kościoła, prowadzi do działa zbawczego Pana Naszego Jezusa Chrystusa" tłumaczenie własne autora, także w kolejnych przypisach.

31 „Przez ekonomię kościelną rozumie się kompetencję Kościoła do wykonywania dzieła zbawczego Naszego Pana Jezusa Chrystusa, uzupełniając z obfitości jego łaski i miłości, w których człowiek w konkretnej sytuacji byłby pozbawiony, gdyby pozostawać w pełnej zgodzie ze świętymi kanonami; $\mathrm{z}$ tego powodu Hierarcha winien mieć bardziej na uwadze zbawienie dusz niż ścisłe przestrzeganie litery prawa".

32 „Hierarcha winien z troską, czujnością i ostrożnością stosować ekonomię oraz chronić, by nie wkradło się nadużycie lub rozluźnienie obyczajów chrześcijan”.

33 „Ekonomia kościelna, przez którą aplikuje się dzieło zbawcze Pana Naszego Jezusa Chrystusa, tak winna być stosowana pod czujnością Hierarchów miejsca, aby tam, gdzie zachowanie ustaw wydaje się trudne na sposób ludzki, niech je uzupełnia miłosierdzie Boże i matczyna miłość Kościoła”. 
na świat, dając mu wszelką władzę niezbędną do spełnienia tej misji, to znaczy zbawienia wszystkich ludzi. Władzę tę Chrystus powierzył z kolei swemu Kościołowi (Mt 28,18). Władza ta rozciąga się na całe posłannictwo pasterskie Kościoła i nie ogranicza się tylko do porządku prawnokanonicznego. Chodzi więc o pojęcie, które przekracza kompetencje właściwe kodeksowi. Wydaje się, że na najbliższym soborze panprawosławnym zostanie do porządku dziennego włączona refleksja nad pojęciem oikonomia, co do którego na razie istnieje wiele rozbieżnych opinii. Międzyprawosławna Komisja Przygotowawcza opracowała już na ten temat dokument badawczy, który ma być przekazany wszystkim Kościołom prawosławnym. Wypada zauważyć, że dokument ten stwierdza, że akribia, czyli pełna zgodność z Ewangelią i kanonami Kościoła, jest środkiem zbawienia dla wszystkich. Co się tyczy ekonomii, jest to władza Kościoła uzupełniająca, w bogactwie jego łaski i miłości to, czego konkretnie brakuje człowiekowi, by był on w pełnej zgodności z Ewangelią i świętymi kanonami. Uzupełnienie jest prawowite i skuteczne, jeśli jest dokonywane (przynajmniej domyślnie) przez hierarchię, która otrzymała od Chrystusa wszelką władzę zbawienia dusz: zapewnia ona możliwość zbawienia nawet człowiekowi, który będąc dobrze usposobiony, znajduje się w stanie antykanonicznym, którego po ludzku nie da się naprawić. Odwołujemy się do ekonomii - kontynuuje ten dokument - właśnie w przypadkach, w których nie da się zastosować akrybii ${ }^{34}$.

W końcowej nocie podano ostateczną propozycję brzmienia ewentualnego przepisu:

Dla przyszłego kodeksu wschodniego nie można niczego innego zaproponować, jak wezwanie skierowane do tych, którzy będą stosować prawa tego kodeksu, by mieli przed oczyma przede wszystkim zbawienie dusz, korzystając przy tym z konieczną roztropnością z epikei, słuszności kanonicznej, tolerancji i innych im podobnych. Można by nawet zaproponować wyrażenie tych myśli we wstępie do całego kodeksu, być może, w sposób następujący: Ekonomia kościelna, na mocy której stosowane jest w odniesieniu do ludzi dzieło zbawcze Pana Naszego Jezusa Chrystusa, winna być sprawowana z duszpasterska troska i pod nadzorem hierarchów; dlatego hierarchowie w stosowaniu prawa kanonicznego będa czuwać bardziej nad zbawieniem dusz, aniżeli nad ścistym zachowaniem litery prawa ${ }^{35}$.

Po wielu dyskusjach w zespołach konsultorów w ożywionej debacie zastanawiano się nad samą stosownością włączenia do kodeksu jakiegokolwiek tekstu na temat ekonomii. Dyskusja doprowadziła konsultorów do jednomyślnej decyzji postanawiającej, by w przyszłym kodeksie prawa nie czynić żadnej

\footnotetext{
${ }^{34}$ Cyt. za: I. ŽUZEK, „L'économie dans le travaux de la Commission”, s. 16.

${ }^{35}$ Tekst kanonu w brzmieniu oryginalnym jest następujący: „Oiconomia ecclesiastica, qua opus salvificum Domini Nostri Jesu Christi hominibus applicatur, sub pastorali sollicitudine et vigilantia Hierarcharum est exercenda; quapropter Hierarchae in lege canonica urgenda magis salutem animarum quam strictam observantiam litterae legis intendant" (tamże, s. 17).
} 
wzmianki na temat ekonomii ${ }^{36}$. Powody takiej decyzji płyną przede wszystkim z samego pojęcia ekonomii, która z jednej strony „wykracza poza kodeks”, a z drugiej - może obejmować wszystkie środki prawne należące do kodeksu, bądź też do tego, co powszechnie nazywane jest praktyką i doktryną kanoniczną, w których mogą znaleźć rozwiązanie przypadki, kiedy to kanony prawa okazują się szkodliwe dla zbawienia dusz. Trzeba przy tym zauważyć, że decyzja podjęta przez konsultorów musi być widziana w aspekcie tego, co zostało $\mathrm{w}$ niniejszym artykule powiedziane na temat ekonomii w powiązaniu z prawodawcą, z duszpasterskim charakterem kodeksu, a zwłaszcza o prawie miłości (którego kodeks jest tylko częścią), a w którym zawierają się wszystkie aspekty ekonomii Bożej przemawiającej za człowiekiem odkupionym przez Chrystusa.

\section{ZAKOŃCZENIE}

Konkluzję może stanowić kan. 1501 KKKW, w którym Prawodawca stanowi: „Jeśli w określonej sprawie brak wyraźnej ustawy, sprawa, z wyjątkiem karnej, winna być rozstrzygnięta według kanonów Synodów i Świętych Ojców, prawnych zwyczajów, ogólnych zasad prawa kanonicznego z zachowaniem słuszności, jurysprudencji kościelnej oraz powszechnej i stałej doktryny kanonicznej" ${ }^{37}$. Z pewnością jej elementem będzie zasada ekonomii, która jako zasada teologiczno-duszpasterska jest dobrą zasadą interpretacji prawa i z pewnością jest sposobem okazania miłosierdzia.

\section{BIBLIOGRAFIA}

\section{ŹRÓDŁA PRAWA}

Codex Iuris Canonici auctoritate Ioannis Pauli PP. II promulgatus (25.01.1983), AAS 75 (1983), pars II, s. 1-317; tekst polski w: Kodeks Prawa Kanonicznego, przekład polski zatwierdzony przez Konferencję Episkopatu, Poznań: Pallottinum 1984.

Codex canonum Ecclesiarum orientalium autoritate Ioannis Pauli II promulgatus, AAS 82 (1990), s. 1034-1363; tekst polski w: Kodeks Kanonów Kościołów Wschodnich promulgowany przez Papieża Jana Pawła II, Lublin: Gaudium 2002.

\footnotetext{
36 Tamże.

${ }^{37}$ Kan. 1501: Si certa de re deest expressum praescriptum legis, causa, nisi est poenalis, dirimenda est secundum canones Synodorum et sanctorum Patrum, legitimam consuetudinem, generalia principia iuris canonici cum aequitate servata, iurisprudentiam ecclesiasticam, communem et constantem doctrinam canonicam.
} 
Sacrosanctum Concilium Oecumenicum Vaticanum II, Constitutio dogmatica de Ecclesia „Lumen gentium" (21.11.1964), AAS 57 (1965), s. 5-71; tekst polski w: SOBÓR WATYKAŃSKI II, Konstytucje, dekrety, deklaracje, Poznań: Pallottinum 2002, s. 478-507.

\section{LITERATURA}

BAURA DE LA PEÑA Eduardo: Misericordia, oikonomia e diritto nel sistema matrimoniale canonico, [w:] Misericordia e diritto nel matrimonio, red. Carlos J. Errázuriz, Miguel Á. Órtiz, Roma: Edizioni Santa Croce 2014, s. 23-45.

DĄBRÓwKA Michał: Istota posługi głoszenia Słowa Bożego w świetle „Mów” św. Leona Wielkiego, „Vox Patrum" 34 (2014), t. 62, s. 93-112.

GrZYwACZ Jerzy: Dyspensa, [w:] Encyklopedia katolicka, t. IV, Lublin: TN KUL 1995, kol. 446.

JARAWAN Elias: Révision des canons De normis generalibus, „Nuntia” 10 (1980), s. 92-94.

MELIA Elie: Le lien matrimonial d la lumière de la théologie sacramentaire et de la théologie morale de l'Eglise orthodoxe, „Revue de droit canonique" 21 (1971), s. 180-197.

PRZEKOP Edmund: Czy zasada tzw. ,ekonomii” wejdzie do kodeksu prawa dla katolickich Kościołów wschodnich, „Studia Płockie” 12 (1984), s. 87-97.

Raport z pierwszej Konferencji Panprawosławnej, „Istina” 18 (1973), s. 372-383.

SOBAŃSKI Remigiusz: Kościół - prawo - zbawienie, Katowice: Księgarnia Świętego Jacka 1979.

SOBAŃSKI Remigiusz: Teoria prawa kościelnego, Warszawa: Wydawnictwo ATK 1992.

SoBAŃSKI Remigiusz: Niezmienność i historyczność prawa w Kościele: prawo Boże i prawo ludzkie, „Prawo Kanoniczne” 40 (1997), nr 1-2, s. 23-44.

SOBAŃSKI Remigiusz: Nauki podstawowe prawa kanonicznego, cz. 1: Teoria prawa kanonicznego, Warszawa: Wydawnictwo Uniwersytetu Kardynała Wyszyńskiego 2001.

SzTAFrowski Edward: Podręcznik Prawa Kanonicznego, t. I, Warszawa: Wydawnictwo ATK 1985.

ŽUZeK Ivan: L'économie dans les travaux de la Commission Pontificale pour la Révision de Code de Droit Canonique Oriental, mps w posiadaniu autora.

ŻUROwSKI Marian: Dyspensowania od prawa powszechnego w świetle Motu proprio De episcoporum muneribus, „Prawo Kanoniczne” 10 (1967), nr 3-4, s. 45-78.

\section{MIŁOSIERDZIE W PRAWIE KATOLICKICH KOŚCIOŁÓW WSCHODNICH}

$$
\text { Streszczenie }
$$

Zagadnienie miłosierdzia w dyscyplinie Katolickich Kościołów Wschodnich obejmuje zarówno przepisy kanonów, w których wprost lub pośrednio prawodawca odwołuje się do tej kategorii teologicznej, jak i przejawia się w stosowaniu odpowiednich instytucji prawnych. Należą do nich dyspensa i ekonomia, które nakazują łagodne stosowanie ustawy kościelnej dla osiągnięcia najważniejszego celu prawa kościelnego, jakim jest pomoc w osiągnięciu zbawienia.

W artykule przywołano uzasadnienie biblijno-teologiczne dla obowiązujących przepisów prawa kanonicznego, stanowiące ratio legis omawianych instytucji prawnych, zwłaszcza doktrynę sformułowaną przez św. Leona Wielkiego i św. Tomasza z Akwinu.

Szczególnie ważnym zagadnieniem w dialogu ekumenicznym z chrześcijanami wschodnimi jest kwestia ekonomii (oikonomia), szeroko stosowana m.in. w Kościołach prawosławnych. Debata nad 
sformalizowaniem tej zasady w katolickim prawie kanonicznym była przedmiotem zainteresowań papieskiej komisji, która przygotowała Kodeks Kanonów Kościołów Wschodnich. Ostatecznie jednak ta zasada wprost nie została zdefiniowana i promulgowana, gdyż uznano, że jest ona realizowana przez zastosowanie innych instrumentów, jak np. dyspensa.

Słowa kluczowe: miłosierdzie; epikeia; dyspensa; akrybia; Kościoły wschodnie

\section{MERCY IN THE CANON LAW OF EASTERN CATHOLIC CHURCHES}

\section{S u m m a ry}

The subject of mercy in the canonical discipline of Eastern Catholic Churches is contained in the canons in which the legislator directly or indirectly recalls such theological category as well as the way of how it is to be applied to various canonical legal instruments. Among those instruments, dispensation and economy specifically dictate a moderate use of the law to obtain the highest purpose of church law, that is, to assist in one's salvation.

The article recalls the biblical-theological rationale for the existing laws in force, that serve as the foundation ratio legis for these two legal instruments, with a particular focus on the doctrine formulated by Saint Leo the Great and Saint Thomas Aquinas.

A very significant subject in the ecumenical dialogue with the oriental Christians is the principle of economy (oikonomia), applied widely among others, especially by the Eastern Churches. An actual debate over formal inclusion of this principle into the Catholic canon law had been a subject of a papal commission that performed the work on the Code of Canon Law of Eastern Churches. In the end, however it has never been defined and promulgated into the body of the law due to the fact it has been concluded that it is already applied when such legal instruments like dispensations are utilized.

Key words: mercy; epikeia; dispensation; akribia; oriental churches 